\begin{tabular}{c} 
Volume and Issues Obtainable at Center for Sustainability Research and Consultancy \\
Journal of Business and Social Review in Emerging Economies \\
ISSN: 2519-089X (E): 2519-0326 \\
Volume 3: Issue 1 June 2017 \\
CSRᄃ \\
Journal homepage: www.publishing.globalcsrc.org/jbsee \\
\hline
\end{tabular}

\title{
Effect of Employee Motivation on Employee Performance
}

\author{
${ }^{1}$ Moeed Ahmad Sandhu, ${ }^{2}$ Javed Iqbal, ${ }^{3}$ Waris Ali, ${ }^{4}$ Muhmmad SajidTufail \\ ${ }^{1}$ Assistant Professor Department of Business Administration BZU Sahiwal, Pakistan, moeed.sandhu@bzu.edu.pk \\ ${ }^{2}$ Lecturer Department of Business Administration BZU Sahiwal, Pakistan, javediqbal@bzu.edu.pk \\ ${ }^{3}$ Assistant Professor Department of Business Administration BZU Sahiwal, Pakistan, waris.ali@bzu.edu.pk \\ ${ }^{4}$ Lecturer Department of Business Administration BZU Sahiwal, Pakistan, sajidtufail@ hotmail.com
}

\begin{tabular}{l}
\hline ARTICLEDETAILS \\
\hline History \\
Revised format: May 2017 \\
AvailableOnline: June 2017 \\
\hline Keywords \\
Employee motivation, \\
employee performance, SMEs, \\
Pakistan
\end{tabular}

JEL Classification:

E24, E29, N15

\begin{abstract}
Purpose:The study empirically analyzes the moderating role of government support policy on the relationship between entrepreneurial orientation, technology orientation and performance of small and medium enterprises (SMEs) in northeast Nigeria.

Design/Methodology/Approach:The paper adopts quantitative survey method using structured questionnaires; data was collected from 240 SME owner-managers in northeast Nigeria. The data collected was analyzed using Partial Least Squares PLS-SEM.

Findings: The findings of the study indicates a significant positive relationship between EO, TO and Performance of SMEs. Additionally, the outcomes of the study authenticate that government support policy moderates the relationship between EO, TO and performance of SMEs in Nigeria.

Implications/Originality/Value:The study have practical implication for government, policy makers, regulators, SMEs owner-managers and other stakeholders to recognize government support as it affects SMEs performance. The study further add to the frontier of knowledge on the importance of GSPs in strengthen the relationship between the variables and SMEs performance.This is the first study that focuses on testing the moderating role of government support policy on the relationship between entrepreneurial orientation, technology orientation and SMEs performance in Nigeria.
\end{abstract}

(C) 2017 The authors, under a Creative Commons AttributionNonCommercial 4.0

Corresponding author's email address: moeed.sandhu@bzu.edu.pk

Recommended citation:Sandhu, M. A., Iqbal, J., Ali, W., Tufail, M. S., (2017)Effect of Employee Motivation on Employee Performance.Journal of Business and Social Review in Emerging Economies, 3 (1),85-100.

DOI:https://doi.org/10.26710/jbsee.v3i1.182

\section{Introduction}

The word motivation is derived from the Latin word motus, a form of the verb which means to move, influence, affect, and excite. By motivation we then mean the degree to which a person is moved or aroused to act. Motivation is the set of psychological processes that cause the arousal, direction, and persistence of individual's behaviors toward attaining a goal. 
The latter definition underlines three pillars of motivation.

- The first - arousal - has to do with the drive or energy that ignites behavior

- The second - direction - has to do with the type of behavior that is exerted and whether it is in line with demand or organization goal

- The third pillar- persistence - deals with the lastingness of behavior. Though, this factor is of less importance, because persistence can be simply defined as the reaffirmation of the initial arousal and direction processes

Motivation is one of the most important concepts of psychology and very vital for the managers who direct the growth of his subordinates towards worthwhile goals. The transfer of control is best supported by an organization environment that is "organized to encourage and support a continued, increasingly mature and comprehensive acceptance of responsibilities for one's own performance"

The concept of motivation is used to explain the distinction between employees which have the same talents, abilities and opportunities to do their jobs in a similar organization and are under the same employment conditions and with the same facilities, but demonstrate different performances. Employees who have high work motivations keep on trying to get more promotion, and since they are constantly seeking better ways to carry out their duties and responsibilities, they will be promoted faster. These employees perform their jobs in such a manner that the jobs are required to be done with relatively more efforts, so they can try more to play the role for which they are asked. Considering the importance of motivation, this research has investigated about the impact of motivation and its related factors on Employees job performance in educational institutions of Sahiwal, Punjab, Pakistan.

The performance of workers has become important due to the increase concern of human resources and personnel experts about the level of output obtained from workers due to poor remuneration. The attitude is also a social concern and is very important to identify problems that are obtained in industrial setting due to nonchalant attitudes of managers to manage their workers by rewarding them well to maximize their productivity. A very few organizations believe that the human personnel and employees of any organization are its main assets which can lead them to success or if not focused well, to decline. Unless and until, the employees of any organization are satisfied with it, are motivated for the tasks fulfilment and goals achievement and encouraged, none of the organization can progress or achieve success. Appropriate reward package can jeer up or influence workers to develop positive attitude towards their job and thereby increase their productivity.

\section{Literature Review}

Internal and external factors that stimulate desire and energy in people to be continually interested and committed to a job, role or subject, or to make an effort to attain a goal.

Motivation results from the interaction of both conscious and unconscious factors such as

(1) Intensity of desire or need

(2) Incentive or reward value of the goal

(3) Expectations of the individual and of his or her peers.

These factors are the reasons one has for behaving a certain way. An example is a student that spends extra time studying for a test because he or she wants a better grade in the class. The job related activities expected of a worker and how well those activities were executed.

Many business personnel directors assess the employee performance of each staff member on an annual or quarterly basis in order to help them identify suggested areas for improvement.

Many characteristics of the work, particularly independence and competence, are referred as intrinsic motivators by social psychologists and personality psychologists. Deci and his colleagues proposed that 
intrinsic motivation occurs when individuals feel both self-determined and competent in their work (Deci 1975; Deci \& Ryan 1985). According to this research, people will feel competent if they obtain feedback that indicates progress in their work, or suggests way they can increase their competence. According to De Cenzo et al., (1996), people who are motivated use a greater effort to perform a job than those who are not motivated. In other words this means that all thinkable factors of physical or psychological aspects that we interact with, leads to a reaction within our self or of the entire organization. When employees have high autonomy, receive feedback about their performance, and have an important, identifiable piece of work to do which requires skill variety, they may experience feelings of happiness and therefore intrinsic motivation to keep performing well (Hackmam\& Oldham, 1980). Motivation has been defined as: the psychological process that gives behaviour purpose and direction (Kreitner, 1995); a predisposition to behave in a purposive manner to achieve specific, unmet needs (Buford, Bedeian, \& Lindner, 1995); an internal drive to satisfy an unsatisfied need (Higgins, 1994); and the will to achieve (Bedeian, 1993) Mitchell. One strategy for reaching higher goals and development is motivation. Employees are motivated to render quality service and effectiveness which means that motivation is a key factor for progress within an institution or organization. A profound knowledge of motivation and its meaning is therefore essential for success of the institution (Paré 2001). Motivating employees is essential for the achievement of organizational goals.

According to Dubin (2002), "Motivation is the complex of forces starting and keeping a person at work in an organization. Motivation is something that puts the person to action, and continues him in the course of action already initiated". Motivation refers to the way a person is enthused at work to intensify his desire and willingness to use his energy for the achievement of organization's objectives. It is something that moves a person into action and continues him in the course of action enthusiastically. Schoeffler (2005), a contributor to the Insurance Journal, explains that incentives should be in a three tier incentive scheme: recognition, short-term, and long term. The basic concept is to allow for incentives that will motivate different personality types. For example, some people enjoy immediate satisfaction and some enjoy satisfaction that is delayed but has taken time to build up. Recognition is a key role in motivating which is a non-financial incentive that reflects feedback.

According to Latham and Ernest (2006) motivation was in the beginning of the 1900s thought only to be monetary. However, it was discovered during the 20th century that to motivate employees, there are more factors than just money. In their view, employees ${ }^{e e}$ satisfaction with their job is an important indicator for a good job performance and happy employees are productive. To them, motivation is a psychological factor and is affected by the workerse mental attitude and health. Therefore, in order to be motivated, a person needs to have certain basic needs fulfilled. If these needs are lacking, a person's self-esteem and self-actualization cannot develop. This could result in lack of interest to progress and develop, both professionally and personally. There are several theories of human needs, which are the foundation of motivation. According to Bassette-jones \& Lloyd (2005) "expectancy, equity, goal setting and reinforcement theory have resulted in the development of a simple model of motivational alignment. The model suggest that once needs of employees are identified, and organisational objectives and also satisfy employee needs .If poorly aligned, then low motivation will be the outcome"

Employee performance fundamentally depend on many factors like performance appraisals, employee motivation, employee satisfaction, compensation, training and development, job security, organization structure and other, but the area of research is focused only on employee motivation as this factor highly influence the performance of employees. A motivational employee is responsive of the definite goals and objectives he/she must achieve, therefore he/she directs their effort in that direction. Ruther fold reported motivation formulates an organization more successful because provoked employees are constantly looking for improved practices to do a work. Getting employees do their best work even in strenuous circumstances, is one of the employees most stable and greasy challenges and this can be made possible through motivating them. 
Employees want to earn reasonable salary and payment and desire their work to feel that is what they are getting. Money is the fundamental inducement; no other incentive or motivational technique comes even close to it with respect to its influential value (Sare et al 2004). It has the supremacy to magnetize and motivate individuals towards higher performance. Research has suggested that reward now cause satisfaction of the employee which directly influences performance of the employee (Kalimullah et al, 2010). All businesses use pay, promotion, bonuses or other types of rewards to motivate and encourage high level performances of employees (Rena et al, 2009). To use salary as a motivator effectively, managers must consider salary structures, payment according to performance, personal or special allowances, fringe benefits and so on( Adeyinka et al 2007).

Performance in organizations can be separated in organisational performance and job performance (Otley, 1999). According to Otley, the performance of organizations is dependent upon the performance of employees (job performance) and other factors such as the environment of the organization. The distinction between organisational and job performance is evident; an organization that is performing well is one that is successfully attaining its objectives, in other words: one that is effectively implementing an appropriate strategy (Otley, 1999) and job performance is the single result of an employee's work (Hunter, 1986). Since the aim of this thesis is to provide a link between motivating employees and their performance, organisational performance lies outside the scope of this research and only job performance is addressed.

A good employee performance is necessary for the organization, since an organization's success is dependent upon the employee's creativity, innovation and commitment (Ramlall, 2008). Good job performances and productivity growth are also important in stabilizing our economy; by means of improved living standards, higher wages, an increase in goods available for consumption, etc. (Griffin et al., 1981). Griffin et al. also argue that therefore research of individual employee performance is important to society in general. According to Hunter and Hunter (1984) crucial in a high job performance is the ability of the employee himself. The employee must be able to deliver good results and have a high productivity. Hunter and Hunter (1984) also argue that this is something the organization can know at forehand; they can select employees with the required abilities or they can recruit those employees themselves. Of course the latter is more time consuming, but can obtain better results in the end (Hunter, 1986).

However, job performance is more than the ability of the employee alone. Herzberg (1959) and Lindner (1998) refer to the managerial side of performance. According to Herzberg (1959) performance is: let an employee do what I want him to do. This implies that the organization's hierarchy and task distribution are also critical for a good employee performance. Lindner (1998) adds to this statement by arguing that employee performance can be perceived as "obtaining external funds". According to Vroom (1964) an employee's performance is based on individual factors, namely: personality, skills, knowledge, experience and abilities. Many researchers agree that job performance is divided in those five factors (e.g. Hunter \& Hunter, 1984). Some researchers even argue that a person's personality has a more specific role in job performance (Barrick \& Mount, 1991). However, according to various researchers, it is not what performance exactly means, but how it is composed and how it is measured (Furnham, Forde \& Ferrari, 1998; Barrick \& Mount, 1991). Vroom's (1964), Hunter \& Hunter's (1984), Hunter's (1986), etc. results are evident. Namely, Job performance can be divided in personality, skills, knowledge, experience and abilities. Some researchers even argue that personality has a more specific role in job performance. However, according to Bishop (1989) and others, job performance contains a problem; namely the measurement of performance.

Individual performance is a core concept within work and organizational psychology. During the past 10 or 15 years, researchers have made progress in clarifying and extending the performance concept (Campbell, 1990). Moreover, advances have been made in specifying major predictors and processes associated with individual performance. 
With the ongoing changes that we are witnessing within organizations today, the performance concepts and performance requirements are undergoing changes as well (Ilgen\&Pulakos, 1999). Performance is a major-although not the only-prerequisite for future career development and success in the labor market. Although there might be exceptions, high performers get promoted more easily within an organization and generally have better career opportunities than low performers (Vans cotter, Motowidlo, \& Cross, 2000).In 1990, Campbell described the literature on the structure and content of performance a virtual desert (p. 704). However, during the past 10 to 15 years, one can witness an increasing interest in developing a definition of performance and specifying the performance concept.

Authors agree that when conceptualizing performance one has to differentiate between an action (i.e., behavioral) aspect and an outcome aspect of performance (Campbell, 1990; Campbell, McCloy, Oppler, \& Sager, 1993; Kanfer, 1990; Roe, 1999). Not every behaviour is subsumed under the performance concept, but only behaviour which is relevant for the organizational goals: Performance is what the organization hires one to do, and do well (Campbell et al., 1993, p. 40). Thus, performance is not defined by the action itself but by judgemental and evaluative processes (cf. Ilgen\& Schneider, 1991; Motowidlo, Borman, \&Schmit, 1997). Moreover, only actions which can be scaled, i.e., measured, are considered to constitute performance (Campbell et al., 1993).

In order to achieve a proper job performance and more effective and optimal efficiency and productivity, each organization explores ways to make a helpful environment for its employees to reach that level of ability which can make a greater impact on their work. Actually, job performance has been defined as the overall values which an individual does during a specified period of time as discrete pieces of behaviors which are expected by the organization (Motowidlo, 2003). Spector expresses that people could act in their careers well, on the condition that they have necessary motives, abilities and motivation to do a good performance (Spector, 2009). Motivation is an individual characteristic, but it can rise from the individual (e.g. personality) and also from the environmental conditions. Improvement and enhancement of organization performance and increment of productivity in order to achieve maximum efficiency of used human and material resources is of the obvious and important management tasks. Rothmann (2002) defines the job performance as a multi-dimensional structure that shows the quality level of working employee's performance, their level of innovation, problem solving techniques and available resources utilization methods, and also their energy and time using manner to perform the duties of the job. In other words, job performance is a set of behavioural and functional patterns including knowledge, skills, managerial competence, conscience and cognitive abilities in the work environment (Murphy and Sharla; quoted from Rothmann, 2002).

\section{Methodology}

In this research, the deductive approach is used. In this approach we utilize a wide range of existing theories and to find the answers from existing research and findings about motivation and employee enhancement, which will form the basis to compare, analyze and investigate the findings of the research. The investigation begins with a sample questionnaire and then results of the questionnaire are analyzed by arranging the motivational factors perceived by employees towards their performance.

The purpose of the research is to access the role of motivation in enhancing employee's performance in educational institutions utilizing Maslow's Hierarchy of need theory as a foundation in order to achieve the same.

Quantitative methods are based on already decided and well-structured questions which all the respondents will be asked. The information is reduced to a certain area of interest.

Our target population is the teachers of the colleges and universities in city Sahiwal of Punjab. A total population size of One Hundred and Twenty (120) respondents is selected. The number of questionnaire 
circulated was 120 out of which 100 were returned. The response rate was $83.3 \%$. All questionnaires were complete and unbiased. This selected sample size gave true reflection of the research findings and fair representative of the respondent views.

\subsection{Research Design}

\subsubsection{Problem Statement:}

This research has been conducted to find out the extent to which the different types of employee motivation can influence the performance of employees in education sector. This research seeks to answer what role motivation play in enhancing employee's performance.

\subsubsection{Research Objective:}

The general objective of the study is to investigate the effect of motivation on the performance of employees. The study seeks to answer following questions:

1. To examine ways of motivating employees to put their best.

2. To assess which factors motivate employees.

3. To evaluate the role that motivation plays on employees performance

4. To establish relationship between motivation and performance

\subsubsection{Research Questions}

1. How does employee motivation affect organizational performance?

2. How do motivational tools affect employees in an organization?

\subsubsection{Hypothesis:}

Our main hypothesis is:

H01: Employee motivation has positive relationship with employee performance.

H02: Financial Incentives and retirement benefits have positive relationship with employee performance.

H03: Job security has positive relationship with employee performance.

H04: Recognition and status is positively related to employee performance.

\subsubsection{Data Collection:}

The data collection instrument used was a structured questionnaire because structured questionnaires are extremely flexible and could be used to gather information concerning almost any topic, from a larger or small number of people. The questionnaire is divided into three sections. Section A collected basic demographic information regarding the respondents such as Path Goal theory age, gender, qualification and working experience; section $\mathrm{B}$ determines the extent to which motivation is practiced by teachers in educational institutions; section $\mathrm{C}$ captured information which explain the extent of an employee performance.

Four of our team members collected data from different educational institutes which were two main universities of the city and other colleges of Sahiwal.

No references were furnished for data collection. We approached the subject matter directly and no appointments were made. Questionnaires were filled free. It means no payments were made to the subject matter. All of the questionnaires were filled and returned by the respondents in four to five days. An average participant took $5-7$ minutes to fill the questionnaire. Some of the questionnaires were filled at the spot. Most of the Questionnaires were filled by the respondents after carefully reading the questionnaire. 


\section{Data analysis and interpretation}

Statistical Packages for the Social Sciences (SPSS) was used in the study for the purpose of analysis and interpretation of results. Descriptive statistics based on frequency tables and graphs was used in the study was based on the tables of frequency distribution and graphical presentation for the responses of work.

\begin{tabular}{|c|c|c|c|}
\hline \multicolumn{4}{|c|}{ Statistics } \\
\hline & Gender & $\begin{array}{l}\text { Area of } \\
\text { Specialization }\end{array}$ & $\begin{array}{l}\text { Educational } \\
\text { Background }\end{array}$ \\
\hline Valid & 100 & 100 & 100 \\
\hline Missing & & & \\
\hline Range & 1.00 & 3.00 & 2.00 \\
\hline Minimum & 1.00 & 1.00 & 1.00 \\
\hline Maximum & 2.00 & 4.00 & 3.00 \\
\hline
\end{tabular}

Statistics table shows that minimum and maximum values are correct and the range is also correct for the three variables namely gender, area of specialization and educational background.

\section{Gender}

\begin{tabular}{|ll|l|l|l|l|}
\hline & & Frequency & Percent & Valid Percent & $\begin{array}{l}\text { Cumulative } \\
\text { Percent }\end{array}$ \\
\hline \multirow{2}{*}{ Valid } & Male & 24 & 24.0 & 24.0 & 24.0 \\
& Female & 76 & 76.0 & 76.0 & 100.0 \\
& Total & 100 & 100.0 & 100.0 & \\
\hline
\end{tabular}

Frequency table for gender shows that $24 \%$ respondents were males and $76 \%$ were females in our research.

\begin{tabular}{|c|c|c|c|c|c|}
\hline & & Frequency & Percent & Valid Percent & $\begin{array}{l}\text { Cumulative } \\
\text { Percent }\end{array}$ \\
\hline Valid & $\begin{array}{l}\text { Arts } \\
\text { Mathematics } \\
\text { Sciences } \\
\text { Business } \\
\text { Total }\end{array}$ & $\begin{array}{l}32 \\
10 \\
36 \\
22 \\
100 \\
\end{array}$ & $\begin{array}{l}32.0 \\
10.0 \\
36.0 \\
22.0 \\
100.0\end{array}$ & $\begin{array}{l}32.0 \\
10.0 \\
36.0 \\
22.0 \\
100.0\end{array}$ & \begin{tabular}{|l|}
32.0 \\
42.0 \\
78.0 \\
100.0
\end{tabular} \\
\hline
\end{tabular}

This table shows that $32 \%$ respondents belong to arts field, $10 \%$ mathematics, $36 \%$ sciences and $22 \%$ to business field.

Educational Background

\begin{tabular}{|ll|l|l|l|l|}
\hline & & Frequency & Percent & Valid Percent & $\begin{array}{l}\text { Cumulative } \\
\text { Percent }\end{array}$ \\
\hline \multirow{4}{*}{ Valid } & Graduate & 5 & 5.0 & 5.0 & 5.0 \\
Masters & 87 & 87.0 & 87.0 & 92.0 \\
& M.Phil & 8 & 8.0 & 8.0 & 100.0 \\
Total & 100 & 100.0 & 100.0 & \\
\hline
\end{tabular}


This table show that 5\% respondents in this research are graduate, $87 \%$ are masters and $8 \%$ are M.Phil.

Explanation:

\begin{tabular}{|c|c|c|c|}
\hline & & $\begin{array}{l}\text { Total } \\
\text { Motivation } \\
\end{array}$ & $\begin{array}{l}\text { Total } \\
\text { Performance }\end{array}$ \\
\hline $\begin{array}{l}\text { Total Motivation } \\
\text { Total Performance }\end{array}$ & $\begin{array}{l}\text { Pearson Correlation } \\
\text { Sig. (2-tailed) } \\
\mathrm{N} \\
\text { Pearson Correlation } \\
\text { Sig. (2-tailed) } \\
\text { N }\end{array}$ & $\begin{array}{l}1 \\
100 \\
.485^{* *} \\
.000 \\
100\end{array}$ & $\begin{array}{l}.485^{* *} \\
.000 \\
100 \\
1 \\
100\end{array}$ \\
\hline
\end{tabular}

Table shows that there is positive correlation (0.485) between employee motivation and employee performance which is also significant at (0.00) level. Therefore we accept this hypothesis.

\subsection{Reliability}

The most important consideration in selecting scale is to check the reliability of the scale. There are a number of different aspects to reliability but the most concerning is internal consistency. One of the most commonly used indicators of internal consistency is Cranach's alpha coefficient. Its value should be above .7.

\subsection{Employee Motivation}

Reliability Statistics
\begin{tabular}{|l|l|l|}
\hline $\begin{array}{l}\text { Cranach's } \\
\text { Alpha }\end{array}$ & $\begin{array}{l}\text { Cranach's } \\
\text { Alpha Based on } \\
\text { Standardized } \\
\text { Items }\end{array}$ & N of Items \\
\hline .747 & .739 & 10 \\
\hline
\end{tabular}

Reliabilty Statistics of Employee Motivation shows it has good internal consistency as the Cronbach's alpha coeffecient value is .747 which is above .7 .

\subsection{Employee Performance}

Reliability Statistics
\begin{tabular}{|l|l|}
\hline $\begin{array}{l}\text { Cronbach's } \\
\text { Alpha }\end{array}$ & N of Items \\
\hline .823 & 9 \\
\hline
\end{tabular}

Reliabilty Statistics of Employee Performane shows it has good internal consistency as the Cronbach's alpha coeffecient value is .823 which is above .7 . 


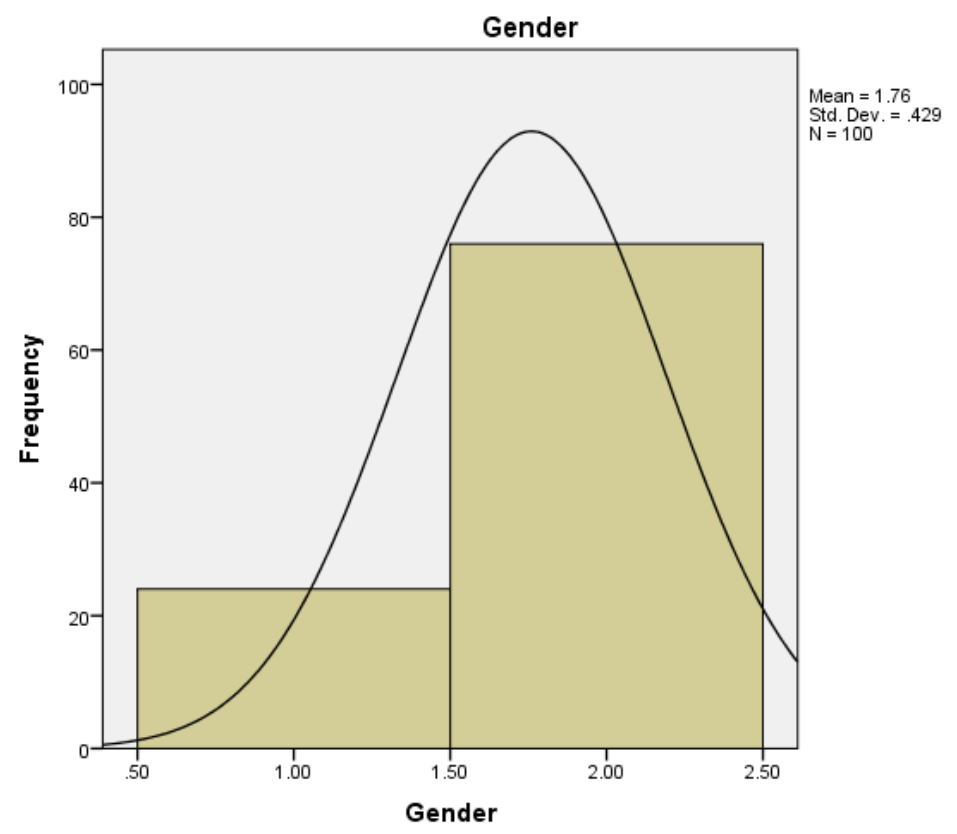

The graph of gender shows the distribution of male and females respondents. Graphs shows that females respondents is $76 \%$ and male respondent is $24 \%$

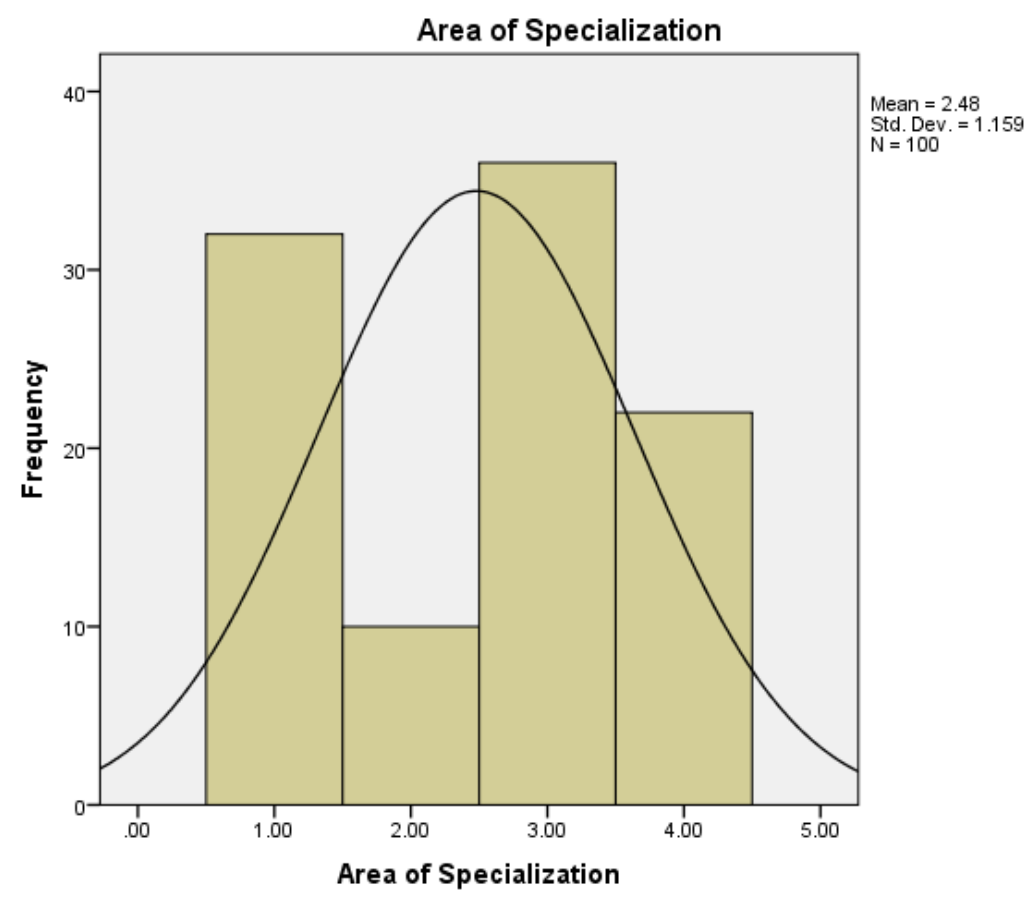

This graphs shows that most of the respondent belong to science field. 


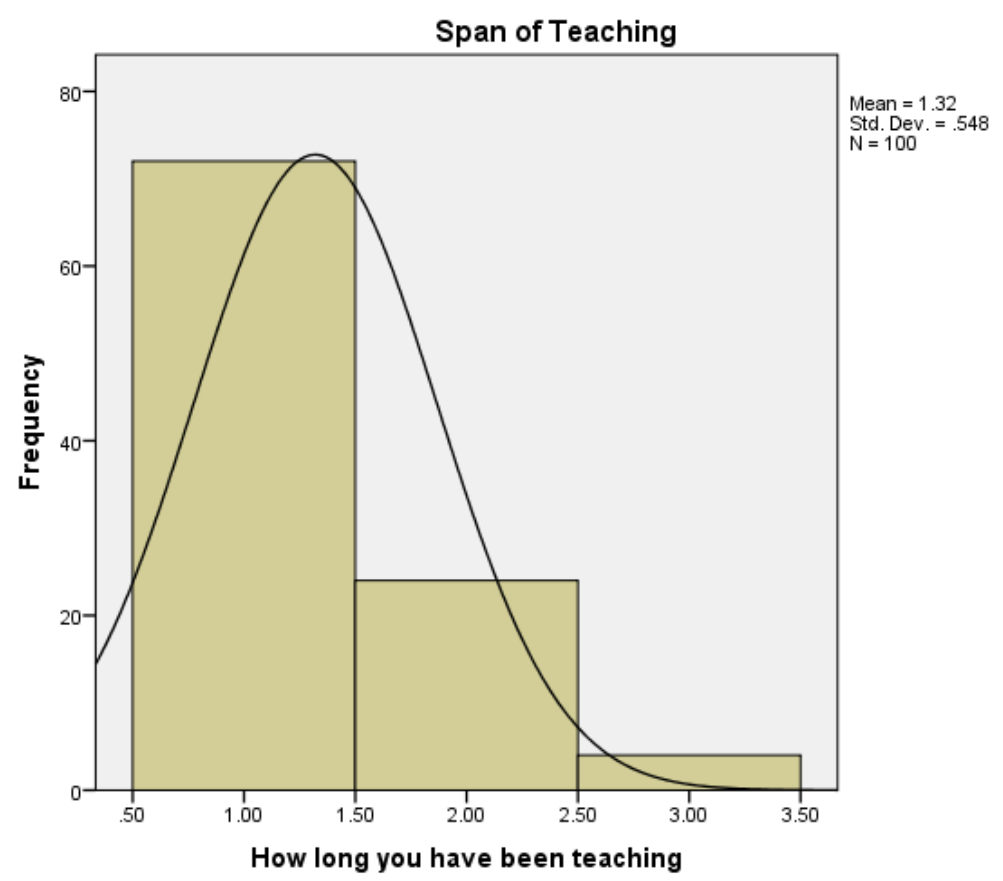

This graph shows that most of the respondents lie within the range of 1-5 years.

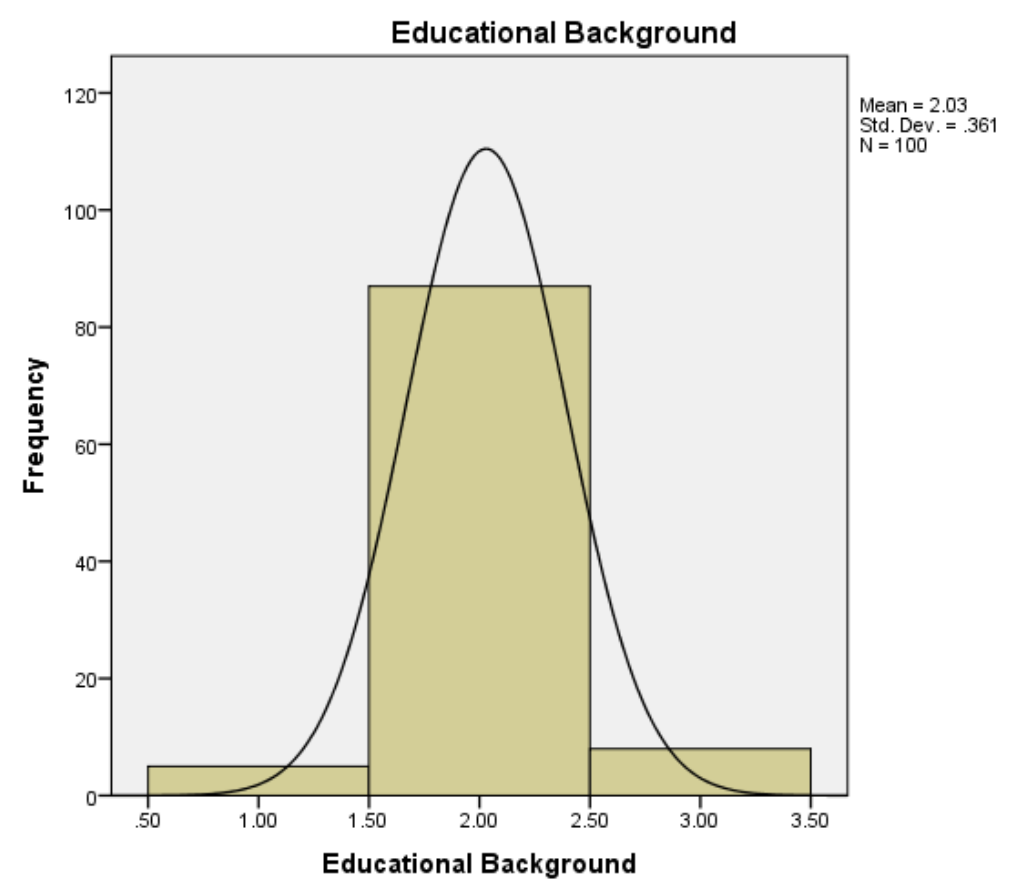

This graphs shows that most of the respondents are masters in their respective fields. 


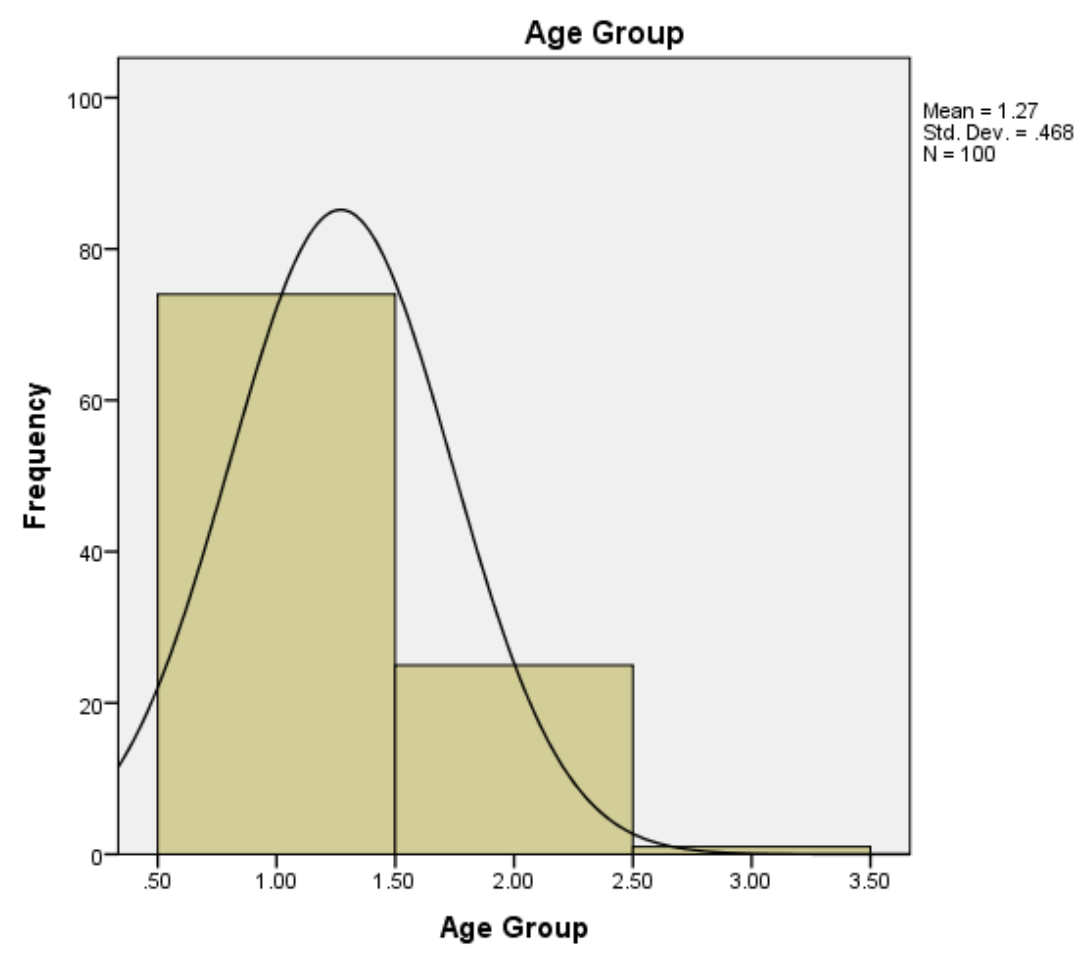

This graph shows that most of the respondents lie within the range of 20-29 years.

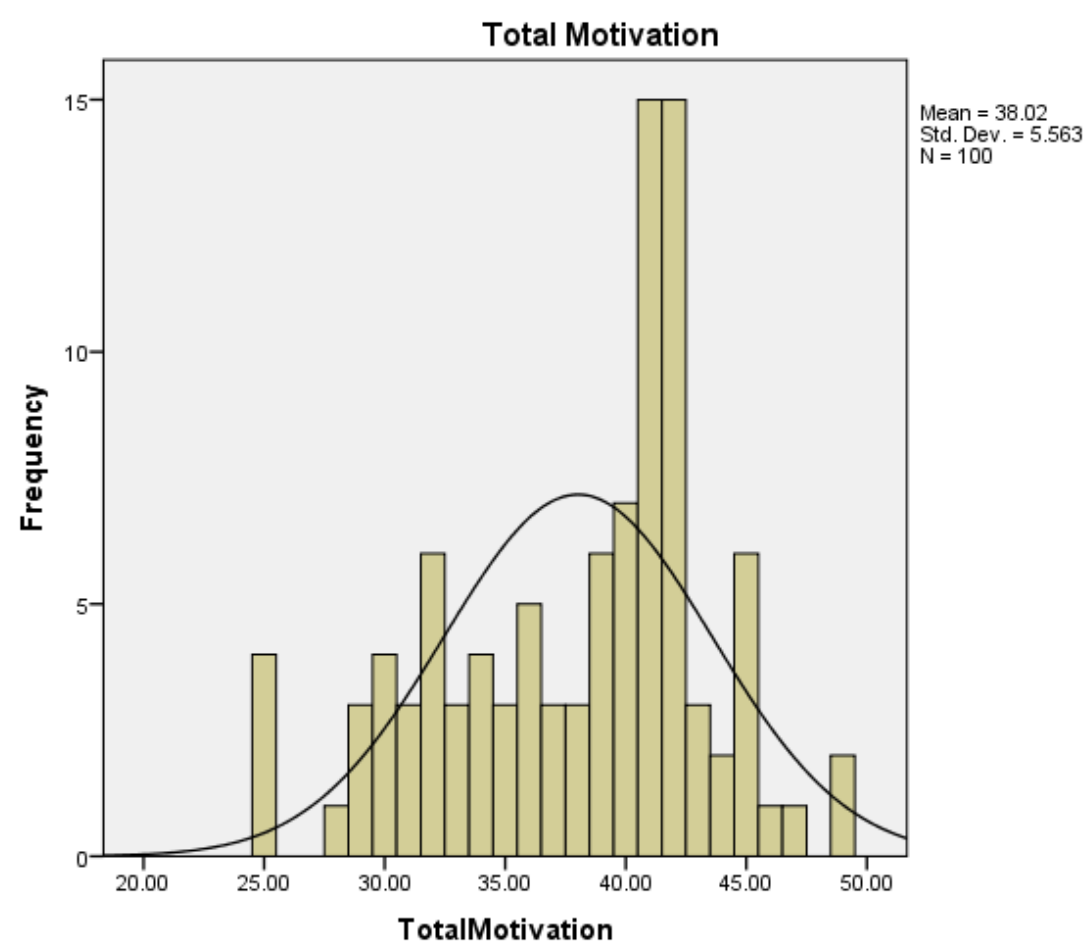

The curve of total motivation shows that curve is normally distributed with some of the values of kurtosis is highly peaked. 


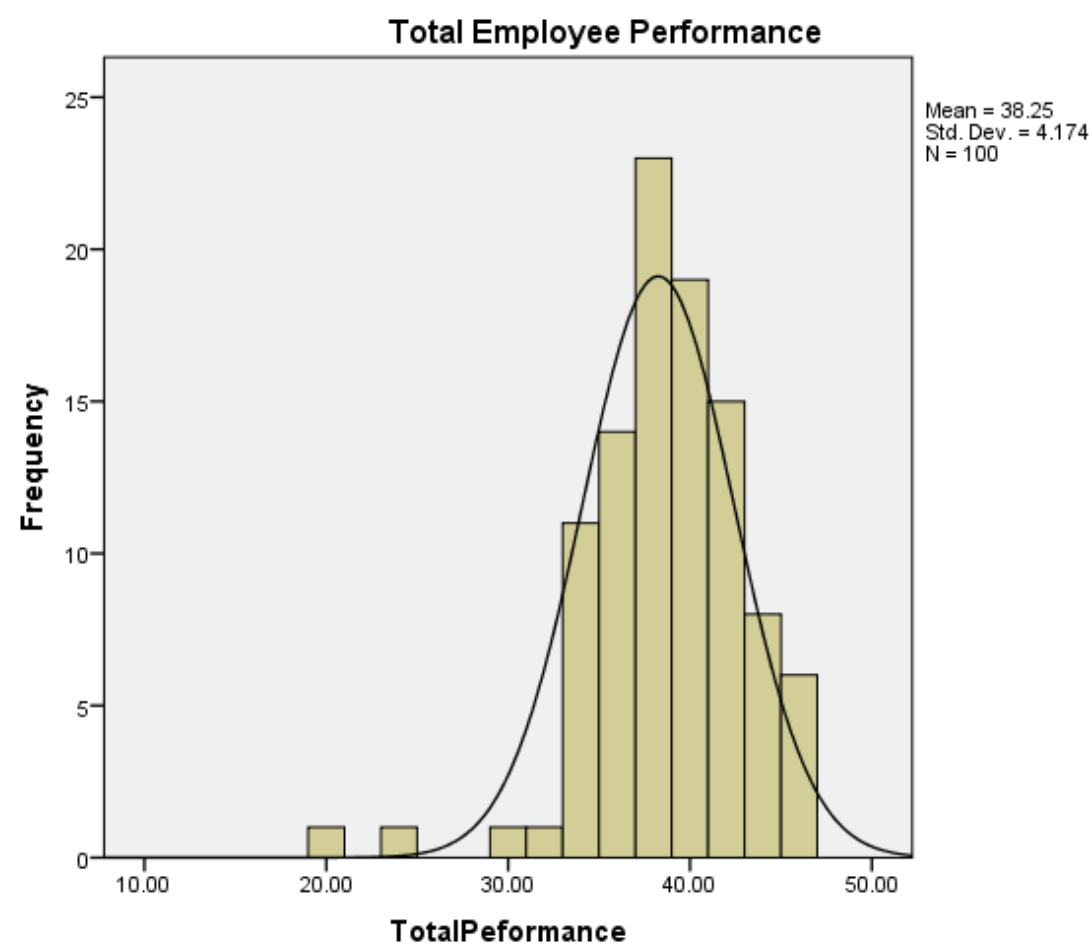

The curve of the total performance shows that the curve is normally distributed with most of the values skewed to the left.

\subsection{Regression}

Descriptive Statistics

\begin{tabular}{|l|l|l|l|}
\hline & Mean & Std. Deviation & $\mathrm{N}$ \\
\hline Total Performance & 38.2500 & 4.17393 & 100 \\
Total Motivation & 38.0200 & 5.56319 & 100 \\
\hline
\end{tabular}

Explanation: This table shows that out of 100 respondents, mean of independent variable employee motivation is 38.02 ; mean of dependent variable employee performance is 38.25 respectively.

\begin{tabular}{|c|c|c|c|}
\hline & & $\begin{array}{l}\text { Total } \\
\text { Performance }\end{array}$ & $\begin{array}{l}\text { Total } \\
\text { Motivation }\end{array}$ \\
\hline \multirow{4}{*}{$\begin{array}{l}\text { Pearson Correlation } \\
\text { Sig. (1-tailed) }\end{array}$} & Total Performance & 1.000 & .485 \\
\hline & Total Motivation & .485 & 1.000 \\
\hline & Total Performance & & .000 \\
\hline & Total Motivation & .000 & \\
\hline \multirow{2}{*}{$\mathrm{N}$} & Total Performance & 100 & 100 \\
\hline & Total Motivation & 100 & 100 \\
\hline
\end{tabular}

\section{Explanation:}

Table shows that there is positive correlation (0.485) between employee motivation and employee performance which is also significant at (0.00)level. Therefore we accept this hypothesis.

Model Summary

\begin{tabular}{|l|l|l|l|l|}
\hline Model & $\mathrm{R}$ & R Square & Adjusted R Square & $\begin{array}{l}\text { Std. Error of the } \\
\text { Estimate }\end{array}$ \\
\hline 1 & $.485^{\mathrm{a}}$ & .235 & .228 & 3.66816 \\
\hline
\end{tabular}

a. Predictors: (Constant), Total Motivation

b. Dependent Variable: Total Performance 
Table indicates the value for adjusted $\mathrm{R}$ square (0.235) which shows that the independent variable (Employee Motivation) explain23.5\% of variance in Employee Performance.

\begin{tabular}{|c|c|c|c|c|c|c|}
\hline Model & & Sum of Squares & Df & Mean Square & $\mathrm{F}$ & Sig. \\
\hline 1 & $\begin{array}{l}\text { Regression } \\
\text { Residual } \\
\text { Total }\end{array}$ & $\begin{array}{l}406.122 \\
1318.628 \\
1724.750\end{array}$ & $\begin{array}{l}1 \\
98 \\
99\end{array}$ & $\begin{array}{l}406.122 \\
13.455\end{array}$ & 30.183 & $.000^{\mathrm{b}}$ \\
\hline
\end{tabular}

a. Dependent Variable: Total Performance

b. Predictors: (Constant), Total Motivation

Coefficients

\begin{tabular}{|c|c|c|c|c|c|c|c|c|}
\hline \multirow[t]{2}{*}{ Mode } & & \multicolumn{2}{|c|}{$\begin{array}{l}\text { Un standardized } \\
\text { Coefficients }\end{array}$} & \multirow{2}{*}{$\begin{array}{l}\text { Standardized } \\
\text { Coefficients } \\
\text { Beta }\end{array}$} & \multirow[t]{2}{*}{$\mathrm{t}$} & \multirow[t]{2}{*}{ Sig. } & \multicolumn{2}{|c|}{ Collinearity Statistics } \\
\hline & & B & Std. Error & & & & Tolerance & VIF \\
\hline \multirow[b]{2}{*}{1} & (Constant) & 24.408 & 2.546 & & 9.586 & .000 & 1.000 & 1.000 \\
\hline & $\begin{array}{l}\text { Total } \\
\text { Motivatio } \\
\mathrm{n}\end{array}$ & .364 & .066 & .485 & 5.494 & .000 & & \\
\hline
\end{tabular}

The independent variable being studied the employee motivation has a greater influence on employee performance with standardised beta coefficient (beta=0.485) which is also significant at 0.000 level.

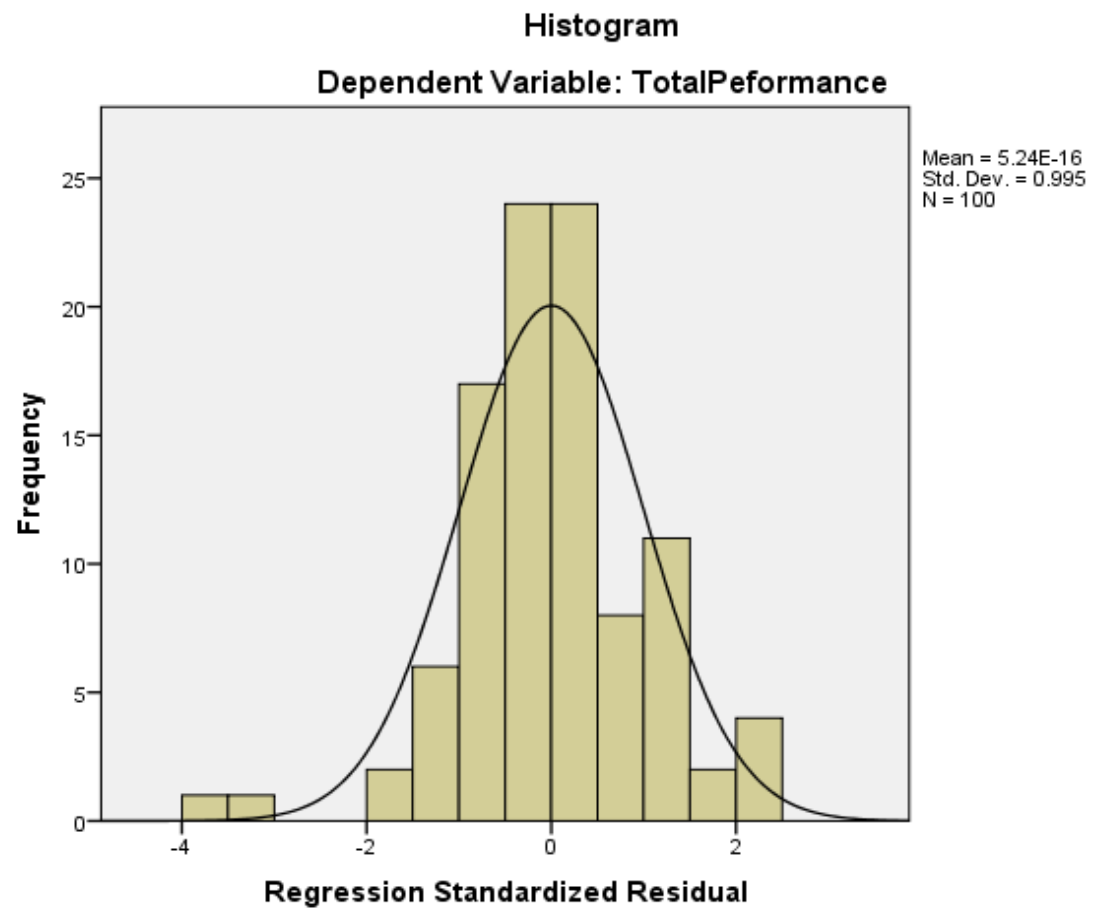

The curve of total employee performance is normally distributed with most of the values lying in the middle of the curve. 


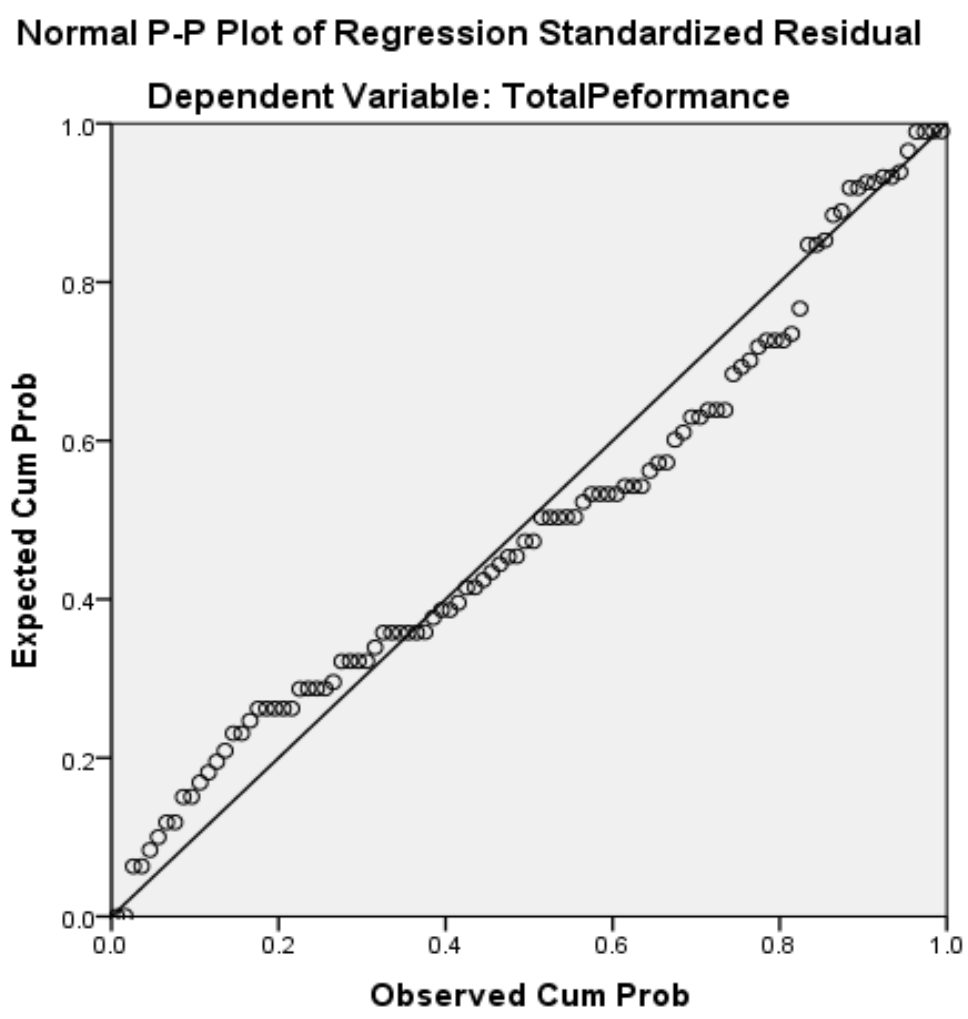

The values of our regression analysis lie almost along the linear regression line which shows the accuracy of data to great extent.

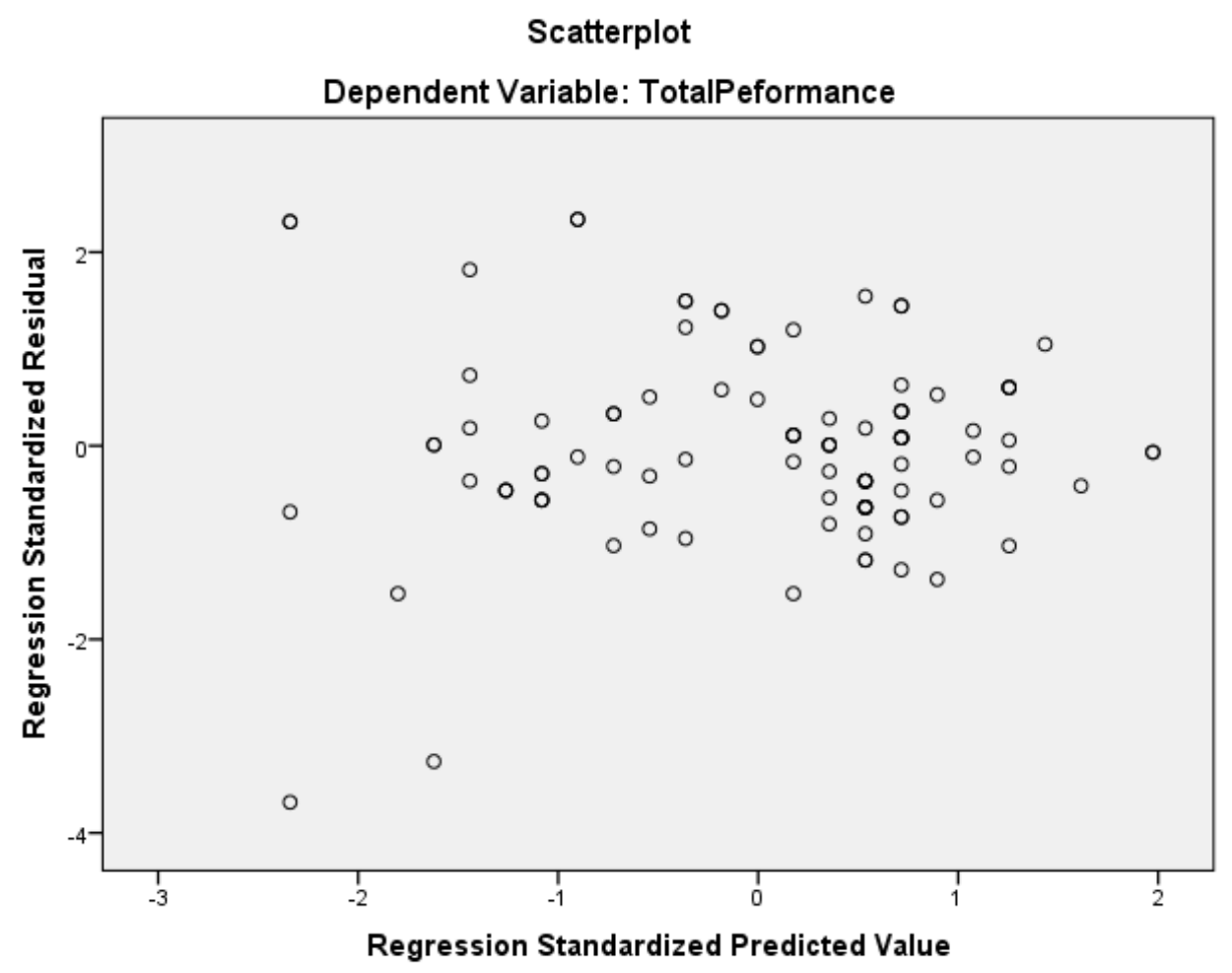

Scatter plot shows that most of the values are clustered in the middle with some of the outliers dispersed around. 


\section{Findings and Discussions}

Answering to hypothesis 1, employee motivation has positive relationship with employee performance. Our questionnaire items show that teachers who are highly motivated and strongly agreed to motivational factors give high performance level.

As regards to second hypothesis financial Incentives and retirement benefits have positive relationship with employee performance. Questionnaire items 2 and 6 were used to show this positive relationship. The research items shows that majority of the teachers were in strongly agreement that's their institutions uses motivational tools such as pay, good working condition, promotion and securities and rewards on formulated organizational policies. Ticking strongly agree to these variables employees that these institution adopt these factors in there motivational process.

\subsection{1st hypothesis}

Employee motivation has positive relationship with employee performance. The first hypothesis which states that, there is a significance relationship between employee motivation and workers performance was accepted. This shows that the kind of motivation given to workers in an organization has a significance influence on workers performance. This is in line with equity theory which emphasizes that fairness in the remuneration package tends to produce higher performance from workers.

\subsection{As regards to 2nd hypothesis}

Financial Incentives and retirement benefits have positive relationship with employee performance. Questionnaire items 2 and 6 were used to show this positive relationship. The research items shows that majority of the teachers were in strongly agreement that their institutions uses motivational tools such as pay, good working condition, promotion and securities and rewards on formulated organizational policies. Ticking strongly agree to these variables implies that these institutions adopt these factors in there motivational process. These findings are consistent with Schoeffler.

\subsection{According to 3rd hypothesis}

Job security has positive relationship with employee performance. Questionnaire items 4 and 5 explain that the mostly teachers are agreed to these variables which shows the positive relationship between job security and employee performance.

\subsection{According to our last hypothesis}

Recognition and status is positively related to employee performance, the strongly agreed response to items 7 and 8 shows that the teachers who get recognition and good status are highly motivated and ultimately benefit the organization with good performance.

As explained in the Maslow's Need Hierarchy theory as the needs of the people fulfilled they are more motivated and directed toward good output. ERG Theory explains that the three factors existence, relatedness and growth must be meted by an employee to enable him, increase performance Social Equity theory describes that the outcome from job includes; pay, recognition, promotion, social relationship and intrinsic rewards.

This all shows that employees getting these motivational factors results in good performance these explanations are consistent with our research hypothesis and findings. Salary, recognition, status, retirement benefits and job security, all of these motivational factors are positively related to good employee performance. At the end the main hypothesis that employee motivation is positively related to employee performance is accepted in accordance with previous researches and our underlying hypothesis with a positive value of Pearson Correlation co-efficient which further explains that increase in motivation by the provision of motivational factors increases employee performance.

The acceptance of research hypothesis also provides answers to both research questions. Moreover our outcomes center out that employee motivation is firmly related to employee performance. 


\section{Limitations of the Study}

Some of the limitations of this research are as follows:

$>$ The quality of the data collected is sufficient for our study, but perhaps not as specific as a lengthier questionnaire could provide. Because the questionnaire was distributed to only some of the educational institutions, the data is not expected to reflect an incredibly wide range of perspectives.

$>$ To apply results to a greater population, a larger, more random sample would need to be taken.

$>$ We face time problem as we are given only 1 week to finalize the questionnaire and get them filled.

$>$ Some respondents show non- serious behaviour in filling the questionnaire

$>$ Another limitation includes the drawing of data from a restricted number of search outputs. Therefore, our search was limited to just one database. A further limitation of this study is the usage of short time-span. This also noticeably reduces the number of relevant articles under consideration.

$>$ More research work is needed in order to find out the extent of the influence of these issues. As we have used a small number of articles, so a comprehensive research is considered necessary to lessen the impact of these limitations and to develop a better understanding of motivation research.

\section{Recommendations}

Based from the conclusion drawn from the findings of the working, the following are recommended:

$>$ The other variables such as rewards, incentives, empowerment etc. can also be used to evaluate employee performance.

$>$ In order to have more accurate results, the subject matter should be more dispersed and should cover wide area.

$>$ Motivation is one of the basic factors in employee working process. So the managers in the educational institutions have to encourage employees and try to enhance motivational techniques to motivate them towards tasks.

$>$ Attitude plays a vital role in the establishment of employee's character and their working process. So the manager's attitude should be friendly and unbiased with everyone.

$>$ Working habits made a great impact on employee working process. So employee should be allowed to select the way to working.

\section{References}

Basset-Jones, N. \& Lloyd, G.C. (2005), “Does Herzberg's Motivational Theory have staying Power"? Journal of Management Development, Vol.24, No.10, pp. 57-56

Friedlander, F. (1966) "Motivation to work and Organisational Performance", Journal of Applied Psychology, Vol. 50, No. 2, pp. 143-152.

Graham, M.W \&Messner, P.E (1998), "Principals and job satisfaction”, International Journal

Of Education Management, Vol. 12, No. 5, pp196-204.

Mitchell, T. R. (1982). Motivation: New directions for theory and research. Academy of Management Review 17(1), 80-88.

Moorhead, G., \& Griffin, R. W. (1998).Managing people and organizations: Organizational behaviour. Boston, MA: Houghton Mifflin Company.

Robbins, Stephen P., \& Judge, Timothy A. (2008). Organizational Behaviour, 13th ed.,

Prentice-Hall.

Robison, Jennifer (2010). Disengagement Can Be Really Depressing, Gallup Management Journal.

Ryan, Richard M., \& Deci, Edward L. (2000). Intrinsic and Extrinsic Motivations:

Classic Definitions and New Directions, Contemporary Educational Psychology 25, Pp.54-67.

Schwartz, Barry (2004). The Tyranny of Choice, Scientific American Magazine, April

Statistics Bundesamt (2010). Personnel of public service institutions, Statistics

Bundesamt, available at:http://www.destatis.de/jetspeed/portal/cms/Sites/destatis/Internet/EN/Content/Statistic. 